\title{
Research in the making
}

Research about research has become something of an arq speciality during the journal's formative years, and this issue is no exception. Leslie Forsyth and colleagues (pp33-43) offer a valuable review of the history of the institutional context for research in UK schools of architecture, and we report on two short conferences held at the RIBA: the first, organised by the Cambridge school (pp13-15); the second, convened by the Institute itself to explore the still vexed issue of design as a form of research (pp17-19). Finally, in an extended and most perceptive letter, Peter Carl reflects on some of the issues raised by the former, and argues that far from being defensive about architecture's seemingly weak position vis à vis traditional academic disciplines, its cross-disciplinary perspective may yet serve as a model in the search for practical wisdom in the shaping of our world.

We will doubtless return to these questions in the future, but with the RAE deadline looming it is our intention to avoid too much navel-gazing and concentrate on publishing papers that contribute to constructing that 'multifaceted vision of the world' which Italo Calvino (in his Six Memos for the Next Millennium) defined as the major task for art in the new century. For architects, a key capability in this search will surely be the rapid closing courtesy of new digital technologies - of the centuries-old division between thinking and making, designing and building, that is the subject of Bob Sheil's paper (pp2o-32). The uses to which Sheil and his colleagues deploy these new techniques may be on the fringes of mainstream practice, but their impact - already apparent in the work of offices as diverse as those of Foster and Gehry - is surely destined to change the way buildings are conceived as well as made.

Keen readers of arq's inside covers - and such there surely are! - will note several changes in this issue. Firstly, we have said thank you and farewell to several members of the Editorial Board who have made valuable contributions during the journal's formative years, and welcomed new members and correspondents who we hope will help us maintain our breadth of interests and increase our geographic reach. And secondly, we would draw attention to significant changes - in particular to the conventions for footnoting and referencing - detailed in the notes for contributors.

THE EDITORS 


\section{architectural research quarterly}

\section{Subscribe now for 2006}

Innovative in conception, unique in breadth

and generously illustrated, this pace-setting

quarterly publication from Cambridge

University Press links, on a global scale,

the worlds of architectural practice and

research. arq regularly includes extensive

peer-reviewed sections on design, history,

theory, construction, environmental design,

information technology and practice - as

well as structures, urbanism and documents.

These are supplemented by letters, reports,

reviews, a directory of specialist research

centers and consultancies and an annual

index. Each issue opens with a leader and

closes with insight, a personal end-piece. In

its three year history, arq has published work

from all over the world: from Chile to Sweden

and from Japan to the Netherlands - with a

strong representation from the United Kingdom

and United States. arq, like architecture itself,

is all-embracing and written by and for both

practitioners and academics. It provides an outlet

for all those who wish to disseminate

their work to an international audience.
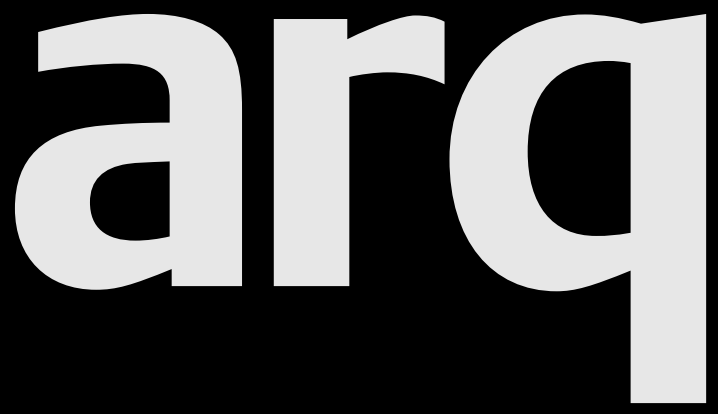

Please enter my subscription to

arq: architectural research quarterly, volume 9, 2005

$\square 145 / \$ 233$ institutions print and electronic

$E_{30} / \$ 50$ students print only

£42/\$64 individuals print only

EU residents only. VAT may be payable at your local rate if not registered.

Our VAT registration number: GB 214141614

If registered, your VAT registration no:

Total subscription payment $€ / \$$

EU residents only, if not registered add VAT at appropriate rate ${ }^{£}$

Canadian residents, add 7\% GST \$

Total $\mathbf{E} / \$$

Name

Address

Payment enclosed

Cheque in sterling or US dollars

(payable to Cambridge University Press)

Credit Card - VISA | MasterCard | American Express (delete where applicable)

Card no

Expiry date

Signature

Photocopy this page and send your order to:

Journals Customer Services, Cambridge University

Press, The Edinburgh Building, Cambridge, CB2 2RU,

UK

$T+44(0) 1223326070$

F +44 (o) 1223315052

E journals@cambridge.org

or in USA, Canada and Mexico send to:

Cambridge University Press, 40 West 2oth Street,

New York NY 10011-4211, USA

T (914) 9379600

F (914) 9374712

E journals_subscriptions@cup.org 